九州大学学術情報リポジトリ

Kyushu University Institutional Repository

\title{
Short circuit in deep brain stimulation
}

\section{左村，和宏}

九州大学医学系学府臓器機能医学専攻

ht tp://hdl. hand le. net/2324/26346

出版情報：九州大学，2012，博士（医学），課程博士

バージョン:

権利関係: (C) American Association of Neurological Surgeons 


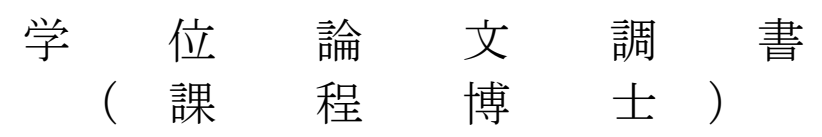

1. 申請者氏名

大学院医学系学府 機能制御医学 専攻 平成 19 年度入学

氏名：左村 和宏

2 . 主論文題名

Short circuit in deep brain stimulation

3. 指導教員名及び認印

4. 主論文の主旨

パーキンソン病 $(\mathrm{PD})$ やジストニアに対する外科的治療として、脳深部刺激 療法があるが、その機械的トラブルの 1 つである回路短絡について研究した。 脳深部刺激装置 (DBS) 植え込み術後の外来患者で、回路短絡発生率は年間 8.9\% であり、DBS 植え込みから回路短絡発見までの平均期間は 64.7 ケであった。 回路短絡の主な症状は、ウエアリング・オフ、開眼失行、構音障害が PD 患者 の 6 例でみられ、全身性ジストニアの患者の 1 例では、ジストニア症状の悪 化がみられた。回路短絡の症例は全例が、DBS のリードをチタン製のミニプ レートで頭蓋骨に固定されていた。電極の設定を変更することで、6 例中 2 例は症状が改善し（症候性：2.5\%）、他の 4 例は改善しなかった。ジストニ アの 1 例は、リードの入れ替え・電極の位置調整を行ったが、症状は改善し なかった。DBS 回路の断線では臨床上の効果が突然失われるのに対して、回 路短絡は回路抵抗が徐々に低下して発症し、バッテリー寿命の短縮だけでな く刺激範囲の減少や拡大により潜行性に臨床症状の進行を引き起こす。DBS 術後の回路短絡発生率は決して低くなくDBSのリードをミニプレートで固定 した症例に多く見られた。DBS 治療歴が長く、特にミニプレートでの固定さ れている症例では、DBSの回路抵抗をルーチンで確認すべきである 